\title{
TECHNOLOGY ENTREPRENEURSHIP AS A FACTOR OF SUSTAINABLE ENERGY IN SMART CITIES
}

\author{
LAZAR D. GITELMAN, MIKHAIL V. KOZHEVNIKOV, \\ EVGENIY M. STARIKOV \& ALEXANDER V. GAMBURG \\ Ural Federal University, Russia
}

\begin{abstract}
The implementation of intelligent engineering infrastructure in cities necessitates the involvement of a large number of various innovative organizations. The experience of pioneer smart cities and global companies that are developing smart technologies shows that the key role in that process is played by technology entrepreneurs, i.e., a community of innovators who are capable of rapidly creating breakthrough solutions, launching them into the market, adopting and commercializing them. This study analyzes the theoretical features and current essential tasks of tech entrepreneurship as a business phenomenon and ways and means for technology entrepreneurship by corporations and independent start-ups. Exploring the case of the energy sector in smart cities which presents a growing market for technology solutions, the authors reveal the structure of the main segments of technology entrepreneurship, including electric vehicles and charging infrastructure, smart metering, telemetering, demand side management, distributed generation and micro-grids. Examples are described of tech entrepreneurship projects that were implemented by energy and telecom companies with the purpose of making urban energy smarter and more sustainable.

Keywords: technology entrepreneurship, sustainable energy, smart city, breakthrough innovation, startup, digital services.
\end{abstract}

\section{INTRODUCTION}

The OECD forecasts that by $2050,66 \%$ of the world's population will live in urban areas. Rapid urbanization results in an extremely high growth in the load on the urban environment: today urban agglomerations account for $75 \%$ of global energy consumption and up to $80 \%$ of carbon emissions [1].

The "smart city" concept is an answer to these challenges. The smart city is typically defined as an integrated system of various information and communication technologies, the internet of things and Big Data for comprehensive real-time management of urban infrastructure [2], [3]. This concept addresses the multiple problems that arise from continuously increasing consumption of resources, energy above all, growing aerial emissions, retrofitting of transport and housing and utilities, and cyber-security. The main goal of a smart city is the improvement of living standards, better services and safety for its dwellers.

The more intense the processes of the implementation of intelligent urban environments, the more saturated they become with the internet and latest telecom technologies and the more significant is the role of energy in ensuring the stable performance of the city. It is no coincidence that the most advanced smart cities pay priority attention to the energy sector, the next electrification stage, and green energy production technologies. Vienna, for example, gets over $15 \%$ of its energy from renewable sources, including Europe's largest biomass power plant [4].

The UAE's Masdar City positions itself as the world's first smart city that is fully powered by solar energy. Jeju Island in South Korea gets its entire energy supply from a distributed network of renewable energy facilities, and operators using automation to balance energy production and consumption. Lappeenranta, a town in Finland, intends to accomplish a 
"green" transition by 2028 and create its own development cluster for knowledge-intensive energy equipment and services. The Finnish smart city project envisages that electricity and steam for heating purposes are generated by biomass-based power plants that burn wood residues. The project also promotes technologies for direct smart energy exchange between consumers [5].

It has to be emphasized that along with radical technology transformations that are taking place in the energy sector of smart cities the sector is embracing a distinct market infrastructure. A prosumer - a proactive consumer who not only consumes but also generates energy - is the new end user of the energy system [6]. Prosumers' participation in the energy market is made possible by adaptive digital networks that enable a prosumer to enter into partnership with the national or municipal energy system or with a neighboring household. Thanks to digital platforms, energy exchange can be commercialized. This paves the way for an internet of energy - an eco-system of producers and consumers who seamlessly integrate into the shared infrastructure and accomplish transactions, that is, trade energy without intermediaries. This gives rise to so-called Connected Smart Grid Systems.

Intelligent energy in cities cannot develop without unhampered access to technological innovations. Rapid development, testing, trials and adoption of technological solutions by various parties involved in the process of innovation become key factors that determine the speed and quality of the "smartization" of cities. Tech entrepreneurs also play a significant role in this process as they convert new knowledge into commercially successful products and services that, as a rule, radically transform the existing markets.

The smart cities segment has a strong commercial appeal to tech entrepreneurs because it grows year-on-year. PWC estimated the smart city market at 737 billion dollars in 2018 and forecasts that it could grow to 2,500 billion dollars in 2025 (Fig. 1). According to Frost and Sullivan, solutions for energy account for around $20 \%$ of the market [7].

As part of this study, we seek to answer questions that have received little coverage in the literature: what functions tech entrepreneurship plays in the energy sector of smart cities,

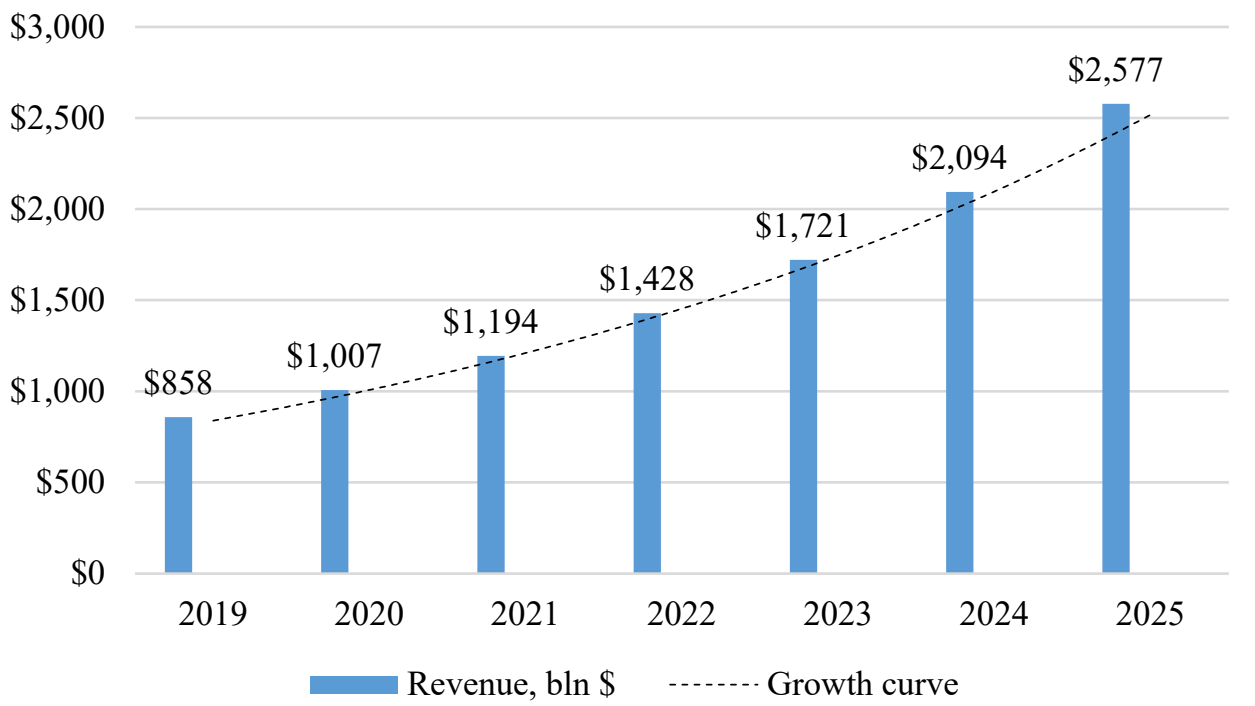

Figure 1: Smart city market value forecast [8]. 
what forms it takes and which technologies are particularly relevant from the point of view of the tech entrepreneurship market amid the digital energy transition.

\section{CONCEPT OF “SMART CITY” AND REQUIREMENTS TO BE MET BY ITS ENERGY SECTOR}

There is a huge variety of smart city concepts that were developed by major companies, think tanks, universities. Having summed up a number of theoretical essays and analytical reports [3], [9]-[14], the authors have drawn up a "smart city" pattern (Table 1) that makes it possible to identify the key technologies in each sector of intelligent urban infrastructure (including energy).

In the context of smart cities, energy has a supra-sectoral status, that is, it has a direct or indirect impact on all other industries. Its development is based on a mix of new imperatives that are to some extent, attributes of the global economy as a whole: de-carbonization, digitalization, customization, development of research-intensive services, greater resource circularity and productivity thanks to decentralized solutions [7], [15]. As a result of their impact on energy systems, a new energy paradigm is arriving. Many countries are already seeing a gradual, element-by-element transition from high-energy fossil fuel systems to profoundly differentiated energy production based on RES, alternative energy use options, distributed generation and hyper-connected micro-grids, active energy consumption models.

The report for the World Economic Forum [16] identifies three main energy trends that will drive radical transformations:

1. A new phase of electrification in manufacturing (especially energy intensive sectors), transport, commercial and domestic segments;

2. Decentralization of the energy system, that primarily refers to a wide use of small-scale generation installations that are located in the closest possible proximity to the consumer; storage systems, overall agility of the energy sector;

3. Digitalization of the grid and connected consumers. Digital technologies should enable maximum real-time control over the energy system, including equipment operation, production management and electricity consumption.

The authors of the report suppose that the implementation of the solutions would produce an exponential decrease in the costs of the adoption of game-changing innovations, improve the asset utilization ratio and, most importantly, spur the emergence of new business models that are based on the provision of digital services and close collaboration with consumers. In the traditional energy paradigm, the consumer is at the end of the value chain. Effectively, he or she has no influence on the parameters of the final service (electricity and thermal energy) or their influence is extremely limited and occurs the moment the service is delivered. The new energy paradigm envisages that the consumer (prosumer) is introduced into the value chain and independently decides how much electricity and thermal energy he needs, when it should be delivered and what its quality (parameters) should be.

Regarding RES, one should bear it in mind that apart from their obvious advantages, such energy sources create an additional load on the energy system due to intermittent generation because an extensive network infrastructure of megalopolises is not capable of integrating and synchronizing a large amount of distributed energy capacity [17]. The core of the solution to the problem is smart buildings (commercial as well as industrial ones) that provide themselves with energy on their own and de facto act as prosumers.

A typical building is a standalone energy-intensive facility that consumers electricity from the centralized grid. In the course of a transition to intelligent urban energy infrastructure, 
Table 1: Technology landscape of smart city.

\begin{tabular}{|c|c|c|}
\hline Sector & $\begin{array}{l}\text { Promising } \\
\text { technology }\end{array}$ & Description \\
\hline \multirow{3}{*}{ Smart energy } & $\begin{array}{l}\text { Distributed } \\
\text { generation }\end{array}$ & $\begin{array}{l}\text { Small capacity generators (e.g. solar panels and wind farms) in } \\
\text { combination with the capabilities of Smart Grid and } \\
\text { accumulators enable consumers to buy and sell electricity and } \\
\text { ensures more efficient energy use thanks to demand side } \\
\text { management programs. }\end{array}$ \\
\hline & $\begin{array}{l}\text { Smart home } \\
\text { and energy } \\
\text { accounting }\end{array}$ & $\begin{array}{l}\text { A combination of sensors using the internet of things in } \\
\text { household appliances and home radiators and in smart } \\
\text { accounting systems makes it possible to analyze consumption } \\
\text { of energy resources, to build the energy profile of the consumer, } \\
\text { optimize the lighting and HVAC procedures, and choose the } \\
\text { most suitable tariffs from a differential menu. }\end{array}$ \\
\hline & $\begin{array}{l}\text { Preventive } \\
\text { maintenance }\end{array}$ & $\begin{array}{l}\text { Equipment inspection robots, mobile repair teams and digital } \\
\text { data bases ensure real-time control over the condition of energy } \\
\text { assets and make it possible to predict equipment failure and } \\
\text { plan maintenance works on the basis of risk strategies. }\end{array}$ \\
\hline \multirow{3}{*}{$\begin{array}{l}\text { Smart city } \\
\text { infrastructure }\end{array}$} & $\begin{array}{l}\text { Street light } \\
\text { control }\end{array}$ & $\begin{array}{l}\text { A combination of sensors and smart grid technology makes it } \\
\text { possible to monitor lighting and adjust the brightness of lighting } \\
\text { based on time of day and weather. }\end{array}$ \\
\hline & $\begin{array}{l}\text { Infrastructure } \\
\text { for electric } \\
\text { vehicles }\end{array}$ & $\begin{array}{l}\text { A complex of charging stations and servicing centers in order to } \\
\text { encourage consumers to use green means of transportation. }\end{array}$ \\
\hline & $\begin{array}{l}\text { Smart } \\
\text { parking }\end{array}$ & $\begin{array}{l}\text { An individual parking space equipped with intelligent sensors } \\
\text { that provides safe and automated car parking. }\end{array}$ \\
\hline \multirow{2}{*}{$\begin{array}{l}\text { Smart road } \\
\text { traffic } \\
\text { management }\end{array}$} & $\begin{array}{l}\text { Real-time } \\
\text { road traffic } \\
\text { management }\end{array}$ & $\begin{array}{l}\text { A combination of smart cameras and motion sensors in cars } \\
\text { enable real-time monitoring and control of the road situation } \\
\text { through digital control centers. }\end{array}$ \\
\hline & $\begin{array}{l}\text { Predictive } \\
\text { maintenance }\end{array}$ & $\begin{array}{l}\text { Various sensors make it possible to monitor the road surface } \\
\text { condition, malfunctions in traffic lights, road information } \\
\text { boards, boom barriers, and to perform preventive maintenance. }\end{array}$ \\
\hline \multirow{2}{*}{$\begin{array}{l}\text { Smart logistics } \\
\text { and planning }\end{array}$} & $\begin{array}{l}\text { Predictive } \\
\text { analytics in } \\
\text { logistics }\end{array}$ & $\begin{array}{l}\text { A combination of neural networks and big data analysis } \\
\text { facilitates the most efficient planning of logistics operations and } \\
\text { makes it possible to predict changes in logistic flows and to } \\
\text { arrange intelligent production logistics. }\end{array}$ \\
\hline & $\begin{array}{l}\text { Warehouse } \\
\text { automation }\end{array}$ & $\begin{array}{l}\text { The use of robots and sensors makes it possible to minimize the } \\
\text { human factor impact on customized production, to accelerate } \\
\text { the product assembly cycle and to eliminate order deliver } \\
\text { errors. }\end{array}$ \\
\hline Entrepreneurship & $\begin{array}{l}\text { Electronic } \\
\text { governance }\end{array}$ & $\begin{array}{l}\text { The digitalization of the process of starting a business, } \\
\text { including various bureaucratic procedures, streamlines and } \\
\text { accelerates many time and resource intensive processes. }\end{array}$ \\
\hline \multirow{3}{*}{ Smart medicine } & $\begin{array}{l}\text { Electronic } \\
\text { health record }\end{array}$ & $\begin{array}{l}\text { A technological solution for pulling together all digitized health } \\
\text { records of a person. }\end{array}$ \\
\hline & $\begin{array}{l}\text { Medical } \\
\text { wearables }\end{array}$ & $\begin{array}{l}\text { Transmit information about the human body and activity online } \\
\text { and enables remote health condition monitoring. }\end{array}$ \\
\hline & Telemedicine & $\begin{array}{l}\text { A complex of technologies for medical out-of-hospital } \\
\text { consultations. }\end{array}$ \\
\hline
\end{tabular}


buildings turn into energy micro-hubs that consume, generate, store and supply electricity. As a result, buildings can be combined into groups that form a micro-grid, and improving the performance and agility of the energy system as such.

Buildings can generate their electricity and consume it centralized sources. This allows for lower electricity bills thanks to consumption management: for example, on-site generated electricity is used during peak hours, with excess being fed into the centralized grid at differentiated prices (Fig. 2).

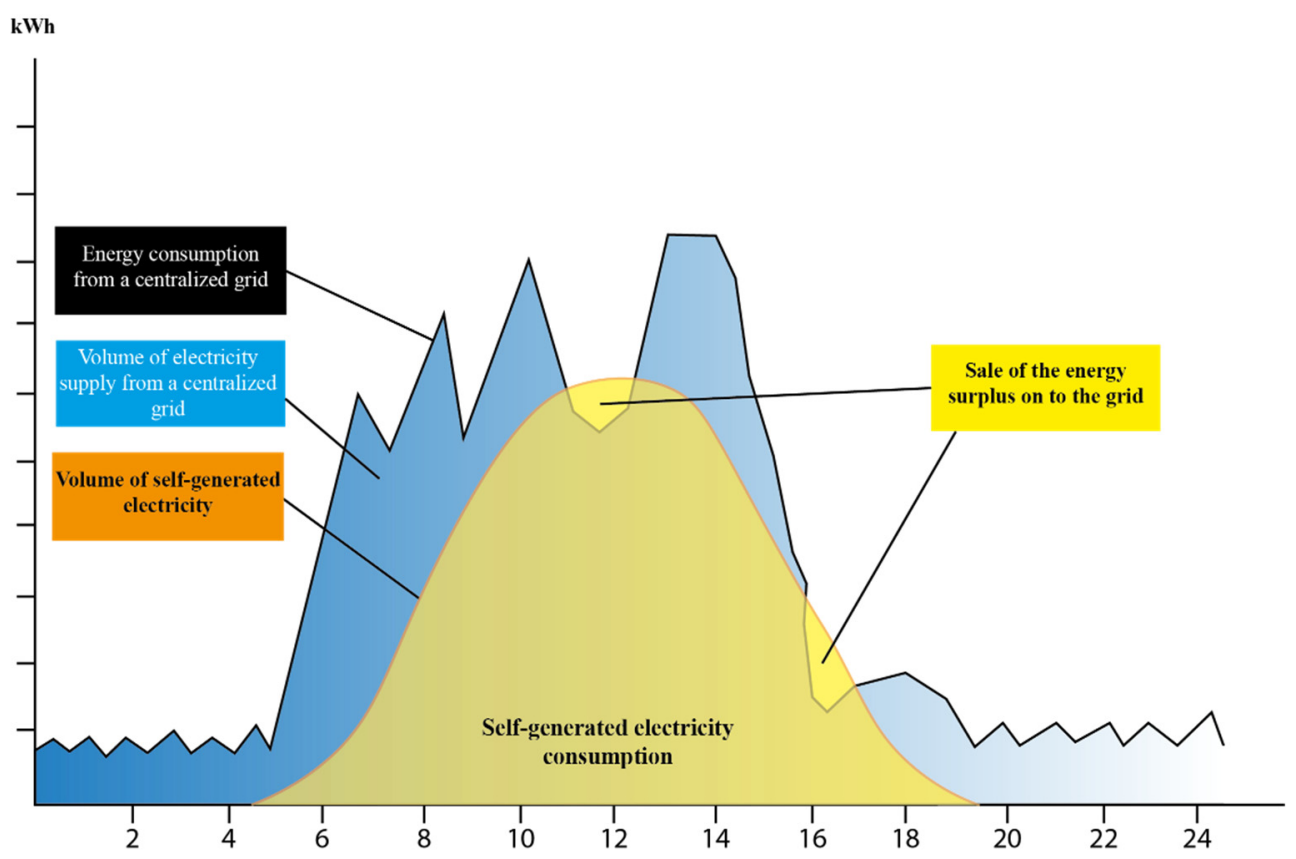

Figure 2: Possible load curve in the case of synchronized use of centralized and off-grid sources.

In the European Union, all new buildings from 2021 are mandated to be nearly zeroenergy buildings, that is, they should technically equip to be self-sufficient in terms of electricity and heat supply. Annually registered reduction in the cost of appropriate technologies supports this goal. For example, the World Energy Council forecasts that the cost of home energy storage devices could drop by as much as $70 \%$ in the next 15 years (Fig. $3)$. Along with energy storage devices, hot water and hydrogen storage systems are considered to have high potential for smarter buildings.

A lot of new technologies are emerging in the segment of smart grids (Table 2). The application of Smart Grid technology first and foremost means greater reliability of electricity transmission, but it also has a number of other related effects. For example, it becomes possible to use lighting infrastructure for rolling out various services: compact $4 \mathrm{G}$ substations, CCTV cameras, digital information boards, electrical outlets, and for peak load and power fluctuation balancing, including through electrified transport [19]. 


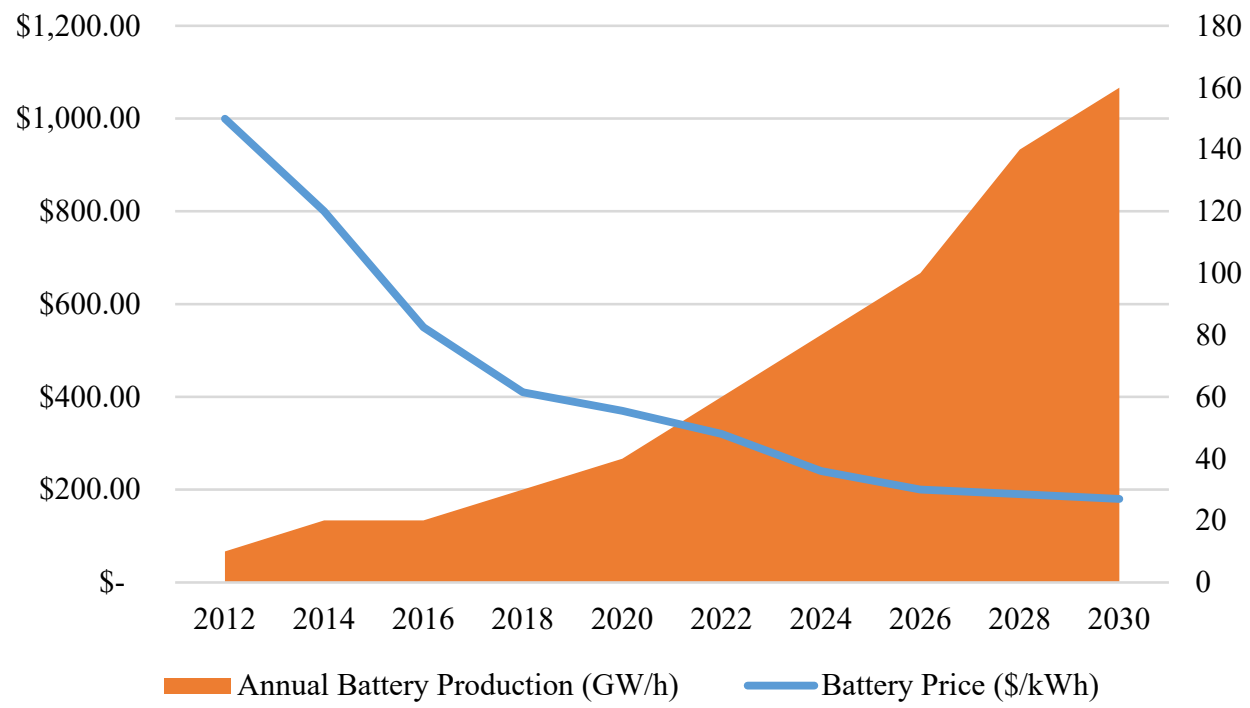

Figure 3: Li-ion batteries - cost and production volume in 2010-2030 [18].

Table 2: Up-to-date smart grid technologies.

\begin{tabular}{|l|l|l|}
\hline $\begin{array}{l}\text { Field of } \\
\text { technology }\end{array}$ & Hardware solutions & Systems and software \\
\hline $\begin{array}{l}\text { Monitoring and } \\
\text { control }\end{array}$ & $\begin{array}{l}\text { Phasor measurement units } \\
\text { (PMU) }\end{array}$ & $\begin{array}{l}\text { Supervisory control and data acquisition } \\
\text { (SCADA), wide-area monitoring systems } \\
\text { (WAMS), wide-area adaptive protection, } \\
\text { control and automation (WAAPCA) }\end{array}$ \\
\hline $\begin{array}{l}\text { Information and } \\
\text { communications } \\
\text { technology }\end{array}$ & $\begin{array}{l}\text { Communication equipment } \\
\text { (LTE, RF-network, mobile } \\
\text { networks), routers, gateways } \\
\text { and switches) }\end{array}$ & $\begin{array}{l}\text { Software for integrated resources } \\
\text { planning, digital consumer information } \\
\text { systems. }\end{array}$ \\
\hline $\begin{array}{l}\text { Transfer } \\
\text { capability } \\
\text { enhancement }\end{array}$ & $\begin{array}{l}\text { Superconductors, flexible } \\
\text { alternating current } \\
\text { transmission system } \\
\text { (FACTS), high voltage direct } \\
\text { current (HVDC) }\end{array}$ & $\begin{array}{l}\text { Analysis of grid robustness, automated } \\
\text { recovery systems }\end{array}$ \\
\hline $\begin{array}{l}\text { Management of } \\
\text { distribution } \\
\text { networks }\end{array}$ & $\begin{array}{l}\text { Condensers with distributed } \\
\text { generation remote control } \\
\text { capability, transformer } \\
\text { sensors }\end{array}$ & $\begin{array}{l}\text { Distribution management system (DMS), } \\
\text { GIS, outage management system (OMS), } \\
\text { workflow management (WMS) }\end{array}$ \\
\hline $\begin{array}{l}\text { Electric vehicle } \\
\text { charging }\end{array}$ & $\begin{array}{l}\text { Batteries, inverters, charging } \\
\text { infrastructure }\end{array}$ & $\begin{array}{l}\text { Payment systems, smart Grid-to-Vehicle } \\
\text { (G2V) charging and Vehicle-to-Grid } \\
\text { (V2G) discharging }\end{array}$ \\
\hline $\begin{array}{l}\text { Consumer } \\
\text { systems }\end{array}$ & $\begin{array}{l}\text { Smart devices (thermostats, } \\
\text { routers, displays), automated } \\
\text { building systems }\end{array}$ & $\begin{array}{l}\text { Solar panels, energy management systems, } \\
\text { energy monitoring apps for smartphones } \\
\text { and tablets }\end{array}$ \\
\hline
\end{tabular}


The above examples of technological opportunities that are opening up in the sphere of smart city energy encourage partnerships between energy companies and entrepreneurs in various industries, universities, research and education centers. Below we examine possible formats for such collaborations and consider their critical role for breakthrough innovations.

\section{ROLE OF TECHNOLOGY ENTREPRENEURSHIP IN ENERGY DEVELOPMENT PROJECTS IN SMART CITIES}

Over the past few decades, cities have become centers of technological development. Scholars exploring this area say that the majority of technologies that are required for turning a city into a smart one are being designed and promoted by technology firms as part of their corporate entrepreneurship strategies [20], [21]. Corporate entrepreneurship is defined as the creation of new businesses by existing companies [22]. Corporate entrepreneurship is often used to foster a strategic overhaul of the line of products and services and to create new competitive advantages [22]-[24].

However, big business efforts prove insufficient for a technology breakthrough. Building upon other authors, Kummitha [25] identifies four groups of players who play a role in building smart cities (Table 3). Interaction between these players happen in the form of public-private partnerships, or in a free market, in which the government mainly acting as a regulator creates and offers access to the necessary infrastructure to parties involved in the technological process, thus encouraging them to create, test and roll out new technological solutions more actively.

Table 3: Players involved in smart city building.

\begin{tabular}{|l|l|}
\hline Player & Role \\
\hline Government & $\begin{array}{l}\text { Makes an effective planning about how to allocate resources and } \\
\text { create effective market policies conducive to the development of } \\
\text { new technologies }\end{array}$ \\
\hline Corporate firms & $\begin{array}{l}\text { Offer technological expertise and knowledge, often in the form of } \\
\text { corporate entrepreneurship }\end{array}$ \\
\hline $\begin{array}{l}\text { Small and medium } \\
\text { enterprises }\end{array}$ & $\begin{array}{l}\text { Create local technologies and services, point solutions that } \\
\text { increase the overall smartization of the city and indirectly boost } \\
\text { the creation of breakthrough technologies }\end{array}$ \\
\hline Citizens & $\begin{array}{l}\text { Actively participate in technology development by generating new } \\
\text { ideas, testing products and providing feedback. }\end{array}$ \\
\hline
\end{tabular}

In our view, it is necessary to add the field of science represented by universities, research centers and, in some cases, consulting companies, to the list of the players described in Table 3 . Science is an active participant in the process of technology transfer between entities of the real sector, enabling them, first, to arrange anticipatory research of technological trends; second, to accelerate the process of knowledge generation, and third, to "filter out" existing incorrect solutions [26].

When the process of technology implementation is already under way, an interesting relationship appears. As the concept of a smart city implies the use of a large amount of data, sensors and the internet, connecting additional technological systems that lead to an increase in the number of infrastructural elements of the smart city gives rise to new market opportunities that other entrepreneurs could take advantage of. 
The same idea is conveyed by PWC in their three-tier development model for smart cities [8]. Tier one includes the creation of base infrastructure and ground-level technology by means of traditional contracting structures between public sector entities and the private sector. Examples might include the creation of a traffic management system, public Wi-Fi, smart streetlighting, or a system for managing and monitoring resource usage in households.

This is necessary for kick-starting a comprehensive overhaul of the city environment and livening up the interest of entrepreneurs in technology development in this or another area.

Tier two is about evaluating the capabilities of the created infrastructure for deploying research-intensive services. Examples might include a transit payment card system that is enhanced into a smartphone and/or facial recognition-enabled payments mechanism that boosts the benefits of smart technologies. The market starts to grow exponentially, attracting even more entrepreneurs.

Tier three is when a digital eco-system starts to develop in and around the city's functioning infrastructure and generates opportunities for a cascade of new products, services and innovation monetization options.

As for smart cities' energy sector, tier one is crucial for the industry. It is necessary to evaluate the technological, investment and energy market preparedness of the energy system to implement intelligent solutions for smart cities. At this tier it might be necessary to carry out profound technological modernization of energy infrastructure. Truly breakthrough services are only possible when "tangible" technologies are properly developed. In this context, technology entrepreneurship constitutes an extremely useful instrument.

Problems of technology entrepreneurship have been a subject of discussion in the scientific community for several decades now and are particularly acute today as new technologies emerge at a faster pace and become increasingly complex [27]-[29]. The authors define technology entrepreneurship as team work by entrepreneurs, investors, engineers, and scientists for the sake of creating breakthrough technologies. Such joint work is fulfilled through continuous search for new opportunities and accumulation of various resources that are needed for a technological solution [30]. At the core of technology entrepreneurship is an innovation that has no rivals in the market, provides the company with long-lasting competitive advantages and creates news key competencies. Technology entrepreneurship can take two main forms: intrepreneurship (an entrepreneurial process happening within the company) and entrepreneurship that implies the creation of a new business (Table 4).

We shall take a look at how various types of technology entrepreneurship are implemented as regards energy projects for smart cities. An example of intrepreneurship is the case of General Electric [31]. In 2011, GE allocated 1 billion dollars for building "digital twins" using machine sensor data that is intellectually gathered and analyzed. The technology helps track wear and tear on aircraft engines, locomotives, gas turbines, and wind turbines using actual data instead of assumptions or estimates, making it easier to predict when they will need maintenance. To implement the project, a corporate research institute - GE Global Research - was founded. GE Global Research designs online programs that teach machine learning and symposia where scientists and business experts could brainstorm new opportunities and creates open spaces for working directly on breakthrough technologies.

In the context of entrepreneurship, an interesting case to be considered is multinational company Shell that started to invest in green energy businesses amid a drop in oil prices [32]. Shell's board of directors made a strategic decision to allocate 1 billion dollars a year for investment in renewable energy, smart construction and energy consumption control technologies. One of the pilot projects was a startup called Inspire Energy Holdings that sells 
Table 4: Types of technology entrepreneurship.

\begin{tabular}{|l|l|l|}
\hline Type & Options & Description \\
\hline \multirow{5}{*}{ Intrepreneurship } & $\begin{array}{l}\text { Establishment of a } \\
\text { new department } \\
\text { within the company }\end{array}$ & $\begin{array}{l}\text { The company uses its own intellectual and } \\
\text { financial resources to organize the } \\
\text { development of new breakthrough } \\
\text { technologies by its new structural unit }\end{array}$ \\
\cline { 2 - 3 } Entrepreneurship & $\begin{array}{l}\text { Tollaborates with } \\
\text { scientists and } \\
\text { consultants }\end{array}$ & $\begin{array}{l}\text { Purchasing a license } \\
\text { to a patent } \\
\text { analysts and outside experts to work in } \\
\text { network project teams creating breakthrough } \\
\text { technologies }\end{array}$ \\
\cline { 2 - 3 } & $\begin{array}{l}\text { Establishment of an } \\
\text { organization outside } \\
\text { the company }\end{array}$ & $\begin{array}{l}\text { Allocating resources for establishing a } \\
\text { subsidiary that would develop innovations } \\
\text { that the company needs }\end{array}$ \\
\cline { 2 - 3 } & $\begin{array}{l}\text { The university conducts a study and converts } \\
\text { it into a patent that is then handed over to a } \\
\text { company for commercial use }\end{array}$ \\
\hline Investing in startups & $\begin{array}{l}\text { Intellectual property is acquired through } \\
\text { purchase/investment in startups and small } \\
\text { technology companies }\end{array}$ \\
\hline
\end{tabular}

wind power at a flat fee. Inspire also provides services of smart control over resources consumption and energy management with the help of a mobile phone app.

Government incentives play a major role in fostering technology entrepreneurship. For example, the government of Melbourne (Australia) has been conducting a campaign encouraging households and SMEs to embrace smart electricity metering systems since 2006. However, a recent survey found that a mere $15 \%$ of people in Melbourne, where smart meters are mandatory, said their metering devices were connected to a special mobile phone application to track and analyze energy consumption. In order to increase the number of users, such applications must be user-friendly and enable one to properly adjust energy use and change the tariff plan depending on their energy behavior. That's why city governments have started to bring pressure on utilities to design such applications that, in their turn, would encourage new energy efficient consumption modes among the population.

The authors' experience of developing the energy sector in smart cities is so far limited to local solutions for automation and digitization of energy facilities in Sverdlovsk Oblast, one of Russia's biggest industrial regions. The lack of expertise in this area is largely due to the absence of appropriate digital law framework and the generally uneven economic and technological development of Russia's regions. The authorities in Moscow and St Petersburg have been able to form a fairly comprehensive vision of a transition to the "smart city" status and even to accomplish some of the projects [33], [34], while other regions are lagging behind. In Sverdlovsk Oblast, "smart energy" advancements have primarily occurred in the field of electric power management at distribution substations and heat consumption management at the level of main meters, allowing for a general consumption picture but failing to deliver control over bills on the consumer side as $90 \%$ of savings can be achieved through consumption control by means of submeters. Households and organizations will not be legally required to installed smart meters until 1 July 2020. 
Nevertheless, telecom company $\mathrm{K}$ Telekom, which is run by one of the authors of this paper, has already implemented a number of projects that aimed to introduce intelligent solutions to the regional energy sector:

- 85 substations of a grid company in Novouralsk were equipped with online electricity and heat consumption monitoring devices;

- 12 nodes of the water supply network in Artemovsky were fitted with a full set of remote metering reading and CCTV systems;

- Some 100 buildings managed by a utility reseller in Zarechny use K Telekom's network for receiving essential power consumption data.

$\mathrm{K}$ Telekom's technology entrepreneurship program is a type of entrepreneurship that is being implemented not only by means of investing in small startups or subsidiaries but also through close cooperation with Ural Federal University. The examples of the latter are the launch of jointly operated communication platforms, new-generation educational products, explorations in the area of the digital transformation of high-tech industries.

\section{CONCLUSION}

Building the energy system of smart cities is a complex knowledge-intensive task that calls for coordinated efforts by various participants. A huge role in the process is played by technology developers and those who test and adopt the technology.

This study aims to stress the need for invigorating technology entrepreneurship as a development driver for sustainable energy in smart cities. Technology entrepreneurship is an activity that focuses on the creation of breakthrough innovations providing companies with long-term competitive advantages and opening up opportunities for acquiring unique key competencies. At the same time, technology entrepreneurship is a useful tool for implementing large-scale projects with the ultimate goal of energy infrastructure transformation, as well as for case-specific efforts aimed at designing individual technical and information services, digitalization of electricity metering systems in households or the implementation of energy efficient solutions in buildings.

In the authors' view, the efficiency of technology entrepreneurship largely depends on "smart partnerships" involving energy companies, universities, vendors of research-intensive services, governments. Such "smart partnerships" could take the form of a platform tailored for exchanging innovative ideas, knowledge transfer, joint research efforts, staff and team training for breakthrough projects. This is particularly relevant to the capital-intensive energy sector that is prone to inertia and is now in the process of convergence with other critical infrastructure industries in cities. The model of the partnership between Ural Federal University and $\mathrm{K}$ Telekom has already started to bear fruit: a series of educational products designed for market analysts and innovative service developers is planned to be launched in the near future; negotiations are under way on technological modernization and digitalization projects with leading energy companies in Sverdlovsk Oblast.

\section{ACKNOWLEDGEMENT}

The work was supported by Act 211 of the Government of the Russian Federation, contract No. 02.A03.21.0006.

\section{REFERENCES}

[1] OECD environmental outlook to 2050. The consequences of inaction. www.naturvardsverket.se/upload/miljoarbete-i-samhallet/internationellt-miljoarbete/ multilateralt/oecd/outolook-2050-oecd.pdf. Accessed on: 15 May 2020. 
[2] Allam, Z. \& Newman, P., Redefining the smart city: culture, metabolism and governance. Smart Cities, 1, pp. 4-25, 2018.

[3] Chourabi, H. et al., Understanding smart cities: An integrative framework. Proceedings of the Annual Hawaii International Conference on System Sciences, 6149291, pp. 2289-2297, 2012.

[4] Caragliu, A., del Bo, C. \& Nijkamp, P., Smart cities in Europe. Journal of Urban Technology, 18(2), pp. 65-82, 2011.

[5] Argunova, M.V., The "Smart City" model as a manifestation of the new technological mode. Science and School, 3, pp. 14-23, 2016.

[6] Gitelman, L.D., Kozhevnikov, M.V. \& Adam, L.A., Sustainable energy for smart city. International Journal of Energy Production and Management, 4(4), pp. 343-353, 2019.

[7] Frost \& Sullivan, Future of energy. Value preposition, 2019.

https://ww2.frost.com/wp-content/uploads/2019/01/Future_of_Energy_Value_ Proposition.pdf. Accessed on: 15 May 2020.

[8] Creating the smart cities of the future. A three-tier development model for digital transformation of citizen services, 2019. www.pwc.com/gx/en/sustainability/assets/ creating-the-smart-cities-of-the-future.pdf. Accessed on: 15 May 2020.

[9] Soe, R.-M., FINEST Twins: Platform for cross-border smart city solutions. Proceedings of the 18th Annual International Conference on Digital Government Research, ed. C.C. Hinnant \& A. Ojo, ACM: New York, pp. 352-357, 2017.

[10] Ohtsuki, T., A smart city based on ambient intelligence. IEICE Transactions on Communications, 100(9), pp. 1547-1553, 2019.

[11] Neirotti, P., De Marco, A., Cagliano, A.C., Mangano, G. \& Scorrano, F., Current trends in smart city initiatives: Some stylised facts. Cities, 38, pp. 25-36, 2014.

[12] Yigitcanlar, T. \& Kamruzzaman, M., Does smart city policy lead to sustainability of cities? Land Use Policy, 73, pp. 49-58, 2018.

[13] Lu, H.-P., Chen, C.-S. \& Yu, H., Technology roadmap for building a smart city: An exploring study on methodology. Future Generation Computer Systems, 97, pp. 727$742,2019$.

[14] Letaifa, S.B., How to strategize smart cities: Revealing the smart model. Journal of Business Research, 68(7), pp. 1414-1419, 2015.

[15] De Groote, M., Fabbri, M., Volt, J. \& Rapf, O., Smart buildings in a decarbonised energy system, 2016. http://bpie.eu/wp-content/uploads/2016/11/BPIE-10-principlesfinal.pdf. Accessed on: 15 May 2020.

[16] World Economic Forum, The future of electricity: New technologies transforming the grid edge, 2017. http://www3.weforum.org/docs/WEF_Future_of_Electricity_2017 .pdf. Accessed on: 15 May 2020.

[17] Dzyuba, A.P. \& Solovyova, I.A., Regional aspects of price-dependent management of expenditures on electric power. Economy of Region, 16(1), pp. 171-186, 2020. (In Russian.)

[18] Hirtenstein, A., Batteries storing power seen as big as rooftop solar in 12 years. www.bloomberg.com/news/articles/2016-06-13/batteries-storing-power-seen-as-bigas-rooftop-solar-in-12-years. Accessed on: 15 May 2020.

[19] Electricity system development: A focus on smart grids. Overview of activities and players in smart grids. www.unece.org/fileadmin/DAM/energy/se/pdfs/eneff/eneff_ h.news/Smart.Grids.Overview.pdf. Accessed on: 15 May 2020.

[20] van den Buuse, D. \& Kolk, A., An exploration smart city approaches by international ICT firms. Technological Forecasting and Social Change, 142, pp. 220-234, 2019. 
[21] Paroutis, S., Bennett, M. \& Heracleous, L., A strategic view on smart city technology: The case of IBM smarter cities during a recession. Technological Forecasting and Social Change, 89, pp. 262-272, 2014.

[22] Sharma, P. \& Chrisman, J.J., Toward a reconciliation of the definitional issues in the field of corporate entrepreneurship. Entrepreneurship Theory and Practice, 23(3), pp. 11-27, 1999.

[23] Hoskisson, R.E., Covin, J., Volberda, H.W. \& Johnson, R.A., Revitalising entrepreneurship: The search for new research opportunities. Journal of Management Studies, 48(6), pp. 1141-1168, 2011.

[24] Zahra, S., Sapienza, J. \& Davidsson, P., Entrepreneurship and dynamic capabilities: A review, model and research agenda. Journal of Management Studies, 42, pp. 917-955, 2006.

[25] Kummitha, R.K.R., Smart cities and entrepreneurship: An agenda for future research. Technological Forecasting and Social Change, 149, $119763,2019$.

[26] Gitelman, L.D. \& Kozhevnikov, M.V., Management consulting for technological modernization and industry of the future. Economy of Region, 13(1), pp. 196-215, 2017. (In Russian.)

[27] Shane, S. \& Venkataraman, S., Guest editors' introduction to the special issue on technology entrepreneurship. Research Policy, 32(2), pp. 181-184, 2003.

[28] Bailetti T., Technology entrepreneurship: Overview, definition, and distinctive aspects. Technology Innovation Management Review, 2(2), pp. 5-12, 2012.

[29] Ratinho, T., Harms, R. \& Walsh, S., Structuring the technology entrepreneurship publication landscape: Making sense out of chaos. Technological Forecasting and Social Change, 100, pp. 168-175, 2015.

[30] Gitelman, L.D., Kozhevnikov, M.V., Starikov, E.M. \& Rada, E.C., Scaling up the innovation process in the energy sector on the basis of technology entrepreneurship. WIT Transactions on Ecology and the Environment, vol. 222, WIT Press: Southampton and Boston, pp. 1-12, 2019.

[31] Woyke, E., General Electric builds an AI workforce. MIT Technology Review, 2017. www.technologyreview.com/s/607962/general-electric-builds-an-ai-workforce. Accessed on: 15 May 2020.

[32] Eckhouse, B. \& Gilblom, K., Shell's pivot to renewables sharpens with California Deal. www.bloomberg.com/news/articles/2018-02-14/shell-makes-another-bet-onrenewable-energy-with-inspire-deal. Accessed on: 15 May 2020.

[33] Moscow "Smart City - 2030". A brief version. https://2030.mos.ru/netcat_files/ userfiles/documents_2030/strategy_tezis_en.pdf. Accessed on: 15 May 2020.

[34] Drozhzhin, S.I., Shiyan, A.V. \& Mityagin, S., Smart city implementation and aspects: The case of St. Petersburg. Electronic Governance and Open Society: Challenges in Eurasia, eds A. Chugunov, Y. Misnikov, E. Roshchin \& D. Trutnev, Springer: Cham, pp. 14-25, 2019. 